\title{
PENGARUH MEDIA STUDENT WORKSHEET TERHADAP HASIL BELAJAR IPS KELAS VIII DI TINGKAT SMP TERPADU OKU TIMUR
}

\author{
Ari Setiawan ${ }^{1}$, Mursilah $^{2}$, Miftakhur Rohmah ${ }^{3}$ \\ 1,2,3 Pendidikan Ekonomi, STKIP Nurul Huda OKU Timur \\ ${ }^{*}$ E-mail: as364903@gmail.com
}

\begin{abstract}
Abstrak: Penelitian ini bertujuan mengetahui pengaruh media student worksheet terhadap hasil belajar IPS kelas VIII di SMP Terpadu Pondok Pesantren Nurul Huda. Penelitian ini merupakan penelitian kuantitatif. Variabel penelitian ini adalah hasil belajar peserta didik, media student worksheet. Populasi dalam penelitian ini adalah seluruh kelas VIII di SMP Terpadu Pondok Pesantren Nurul Huda sebanyak 115 peserta didik, sampel dalam penelitian ini terdapat dua kelas yaitu kelas VIII.B sebagai kelas ekperimen berjumlah 28 siswa sedangkan kelas VIII.D sebagai kelas kontrol berjumlah 27 peserta didik. Teknik pengumpulan data menggunakan angket dan tes. Metode analisis yang digunakan adalah uji t. Dari hasil penelitian Pengaruh media student worksheet berpengaruh terhadap hasil belajar IPS kelas VIII di SMP Terpadu Pondok Pesantren Nurul Huda yang ditunjukkan dengan nilai kuesioner kedua kelas VIII.B eksperimen memiliki nilai tertinggi sebesar $89,3 \%$ sedangkan kelas VIII.D kontrol sebesar $74,1 \%$ dari nilai tersebut terlihat bahwa hasil belajar eksperimen lebih tinggi dibandingkan kelas kontrol. Sig sebesar 0,000. Karena nilai sig 0,05 maka $\mathrm{HO}$ diterima.
\end{abstract}

Kata Kunci: Media Student Worksheet, Hasil Belajar IPS.

\section{PENDAHULUAN}

Pendidikan mempunyai peran yang penting pada era globalisasi karena untuk meningkatkan kualitas sumber daya manusia. Pendidikan merupakan suatu kualitas yang sangat perlu diperhatikan terus menerus karena untuk melihat perkembangan di Indonesia yang dilakukan oleh pemerintah. Pada IImu Pengetahuan Sosial (IPS) merupakan mata pelajaran yang diajarkan dalam rangka mewujudkan suatu tujuan pendidikan nasional.

Menurut Undang-Undang No. 20 Tahun 2003 Pasal 3 yang disusun suatu undang-undang mengenai sistem pendidikan nasional. Diantaranya menjelaskan tentang tujuan pendidikan nasional yang menyatakan bahwa:

"Pendidikan nasional adalah berfungsi mengembangkan kemampuan dan membentuk watak serta peradaban bangsa yang bermartabat 


\title{
PENGARUH MEDIA STUDENT WORKSHEET TERHADAP HASIL BELAJAR IPS KELAS VIII DI TINGKAT SMP TERPADU OKU TIMUR
}

\begin{abstract}
dalam rangka mencerdaskan kehidupan bangsa, bertujuan untuk berkembangnya potensi peserta didik agar menjadi manusia yang beriman dan bertakwa kepada Tuhan Yang Maha Esa, berakhlak mulia, sehat, berilmu, cakap, kreatif, dan menjadi warga negara yang demokratis serta bertanggung jawab"
\end{abstract}

Adanya kurikulum 2013 diharapkan kondisi pendidikan akan mengalami peningkatan yang baik agar sumber daya manusia di Indonesia memiliki kompetensi masa depan yang unggul sehingga dapat bersaing menghadapi tantangan masa depan yang semakin kompetitif.

Belajar ialah suatu proses usaha yang dilakukan seseorang untuk memperoleh suatu perubahan tingkah laku yang baru secara keseluruhan, sebagai hasil pengalamannya sendiri dalam interaksi dengan lingkungannya (Slameto, $2010: 2$ ). Sedangkan menurut (Hamalik, 2013 : 27) menyatakan bahwa belajar merupakan suatu proses, suatu kegiatan dan bukan suatu hasil atau tujuan. Belajar bukan hanya mengingat, akan tetapi lebih luas dari itu, yakni mengalami. Hasil belajar bukan suatu penguasaan hasil latihan melainkan pengubahan tingkah laku. Maka dari itu peserta didik yang belajar diharapkan mengalami perubahan yang baik dalam bidang pengetahuan, pemahaman, ketrampilan nilai dan sikap.

Pembelajaran merupakan proses yang didalamnya terdapat kegiatan interaksi antara dua pihak yaitu guru dan siswa dengan berkomunikasi ada timbal balik yang berlangsung dalam situasi edukatif untuk mencapai tujuan belajar (Rustaman, 2001:461). Proses pembelajaran adalah segala upaya bersama antara guru dan siswa untuk berbagi dan mengolah informasi, dengan harapan pengetahuan yang diberikan bermanfaat dalam diri siswa dan menjadi landasan belajar yang berkelanjutan. Hal ini disebabkan oleh proses pembelajaran siswa yang berbedabeda pula, ada sikap siswa yang terlibat aktif dalam suatu interaksi edukatif, juga ada siswa yang bersikap kurang aktif.

Media Student Worksheet atau yang lebih dikenal Media Lembar Kerja Siswa (LKS) merupakan bahan ajar cetak berisi materi, ringkasan dan petunjuk-petunjuk pelaksanaan tugas pembelajaran yang harus dikerjakan oleh siswa dan mengacu pada kompetensi dasar yang harus dicapai (Prastowo, 2011). LKS merupakan salah satu media belajar yang terdiri dari satu atau beberapa lembar kertas yang dibagikan kepada siswa pada suatu kelas, dengan tujuan agar siswa melakukan kegiatan belajar sesuai yang tertera atau tercantum dalam lembar kegiatan LKS. Dimaksudkan supaya siswa melakukan kegiatan belajar yang efektif.

Demikian, hal yang merupakan paling penting bagi para pengajar untuk menambah wawasan tentang media student worksheet yang telah diketahui. Dengan menguasai media yang akan diterapkan, maka tujuan pembelajaran akan lebih mudah tercapai dan sesuai yang diharapkan. Hanya saja satu masalah yang dihadapi di SMP Terpadu Pondok Pesantren Nurul Huda ialah hasil belajar peserta didik pada mata pelajaran IPS masih banyak yang belum mencapai nilai KKM.

Dari penjelasan tersebut, siswa dituntut untuk memiliki pemahaman yang baik 
Ari Setiawan ${ }^{1}$, Mursilah $^{2}$, Miftakhur Rohmah ${ }^{3}$

terhadap konsep mata pelajaran IPS. Pembelajaran IPS diharapkan mampu menciptakan paradigma terhadap kegunaan IPS dalam kehidupan. Peran guru dalam menyampaikan materi pembelajaran akan berpengaruh terhadap semangat belajar peserta didik dalam mengikuti pembelajaran dan berdampak pada hasil belajarnya. Dalam mencapai sebuah tujuan pembelajaran hendaknya seorang pendidik dapat memanfaatkan media student worksheet yang dapat meningkatkan keaktifan peserta didik dalam kegiatan pembelajaran, untuk itu guru harus memiliki kompetensi dan peran yang sesuai dalam pembelajaran untuk meningkatkan kualitas dan siswa merasa tertarik untuk mengikuti pembelajaran, sehingga hasil belajar tercapai secara maksimal.

Berdasarkan hasil observasi yang dilakukan oleh peneliti pada tanggal 10 September sampai 10 November 2018 di SMP Terpadu Pondok Pesantren Nurul Huda. Khususnya dalam kegiatan pembelajaran mata pelajaran IPS dimana guru tersebut cukup variatif dan disisi lain guru masih ada yang memanfaatkan fasilitas pembelajaran misalkan guru melakukan proses pembelajaran mata pelajaran IPS, tetapi pada pembelajaran mata pelajaran IPS guru tersebut tidak pernah menggunakan fasilitas seperti LCD proyektor.

Ketika proses belajar mengajar berlangsung dapat mempengaruhi prestasi belajar siswa yang seharusnya mencapai yang diharapkan tetapi justru sebaliknya kurang mencapai yang diharapkan baik dengan siswa mapun guru. Hal ini terlihat dari antusiasme siswa yang cukup rendah ketika siswa mengikuti pelajaran, ada siswa yang tidur pada saat proses belajar mengajar berlangsung dan ada juga siswa yang bercerita dengan temannya, bahkan ada siswa yang tidak mengikuti proses belajar mengajar dikelas.

Pada saat pembelajaran siswa merasa bosan karena sering mendengar, mencatat dan mengerjakan soal sehingga siswa kurang termotivasi dalam mengerjakan soal-soal. Padahal jika LKS digunakan, hal utama yang menjadi keunggulannya yaitu siswa tidak perlu lagi banyak mencatat karena ringkasan materi sudah tertera didalam LKS tersebut. Hanya saja siswa perlu mendengarkan guru dan sedikit mencatat kemudian mereka lebih banyak mengerjakan soal-soal.

Dengan adanya permasalahan tersebut, maka tujuan pembelajaran terbilang kurang maksimal, sehingga hasil belajar peserta didik masih belum mencapai standar ketuntasan belajar. Untuk mengatasi permasalahan ini, maka yang dilakukan peneliti adalah menggunakan media student worksheet. Metode pembelajaran ini digunakan karena sesuai dengan karakteristik belajar siswa dalam pembelajaran IPS.

\section{METODE}

Penelitian ini akan mengkaji tentang pengaruh media student worksheet terhadap hasil belajar IPS kelas VIII di SMP Terpadu Pondok Pesantren Nurul Huda. Penelitian ini memiliki satu variabel bebas dan satu variabel terikat. Variabel bebas penelitian ini adalah media student worksheet, sedangkan variabel terikat pada 


\section{PENGARUH MEDIA STUDENT WORKSHEET TERHADAP HASIL BELAJAR IPS KELAS VIII DI TINGKAT SMP TERPADU OKU TIMUR}

penelitian ini adalah hasil belajar IPS.

Jenis penelitian ini adalah penelitian kuantitatif. (Sudjana, 2010:18) menjelaskan, "penelitian kuantitatif suatu metode penelitian yang berlandaskan sebagai satu-satunya sumber pengetahuan yang benar dan digunakan untuk meneliti pada populasi atau sampel tertentu, pengumpulan data menggunakan instrumen penelitian, analisis data bersifat statistik dengan tujuan untuk menguji hipotesis".

Desain penelitian yang digunakan adalah penelitian eksperimen atau True Experimental Design. (Sugiyono, 2012:72) "penelitian eksperimen atau True Experimental Design yaitu untuk mencari pengaruh perlakuan tertentu terhadap yang lain dalam kondisi yang terkendalikan". Desain penelitian ini menggunakan Posttest Only Control Design yang terdapat dua kelompok, yaitu kelompok eksperimen dan kelompok kontrol.

Populasi pada penelitian ini adalah seluruh kelas VIII di SMP Terpadu Pondok Pesantren Nurul Huda yang berjumlah 115 peserta didik dan terbagi dalam empat kelas yaitu VIII-A, VIII-B, VIII-C, VIII-D. Dan jumlah populasi lebih dari 100, maka seluruh populasi dalam pengambilan penelitian ini menggunakan teknik random sampling. Berdasarkan pengambilan sampel tersebut, nomor yang keluar akan dijadikan sampel, kelas yang diambil dalam penelitian adalah kelas VIII-B dan VIII-D dan dijadikan sebagai sampel dalam penelitian.

Teknik pengumpulan data yang digunakan pada penelitian ini adalah angket dan tes. Sebelum digunakan instrumen penelitian tes diuji terlebih dahulu tingkat kevalidan menggunakan korelasi product moment, uji reliabilitas menggunakan alpha cronbach, taraf kesukaran dan daya pembeda. Setelah data terkumpul, dilakukan uji analisis data yaitu uji normalitas menggunakan program SPSS versi 20 dan uji homogenitas menggunakan program SPSS versi 20. Setelah data dinyatakan normal, maka dilakukan analisis data menggunakan uji t.

\section{HASIL DAN PEMBAHASAN}

Media student worksheet terhadap hasil belajar IPS diketahui menggunakan instrumen angket dan tes. Instrumen angket disusun 20 berbentuk pertanyaan dengan skor 4 jawaban yaitu sangat setuju (4), setuju (3), tidak setuju (2), sangat tidak setuju (1). Instrumen Tes disusun 20 nomor berbentuk pilihan ganda dengan 4 opsi jawaban yaitu a, b, c, dan d. Jika peserta didik menjawab benar mendapatkan skor 1 dan jika salah mendapatkan skor 0 .

Penelitian ini memiliki dua jenis varibel yaitu variabel independen atau bebas dan variabel dependen atau terikat. Pada uraian bab ini akan dipaparkan tentang hasil data yang diolah adalah hasil belajar. Penelitian dilakukan terhdap dua kelas, yaitu kelompok eksperimen (Kelas VIII.B) dengan jumlah siswa sebanyak 28 siswa diberikan perlakuan ekperimen dengan menyebarkan angket tentang student worksheeet dan kelompok kontrol (Kelas VIII.D) dengan jumlah siswa sebanyak 27 siswa yang diberikan perlakuan kontrol dengan menyebar angket tentang pelajaran 
IPS. Data-data hasil penelitian kedua variabel dapat disajikan dengan menggunakan alat bantu program spss versi 20.

Tabel 1. Descriptive Statistics

\begin{tabular}{|l|c|c|c|c|c|c|c|c|}
\hline & $\mathrm{N}$ & Range & Min & Max & \multicolumn{2}{|c|}{ Mean } & $\begin{array}{c}\text { Std. } \\
\text { Deviatio } \\
\mathrm{n}\end{array}$ & Variance \\
\cline { 2 - 7 } & Statistic & Statistic & Statistic & Statistic & Statistic & $\begin{array}{c}\text { Std. } \\
\text { Error }\end{array}$ & Statistic & Statistic \\
\hline $\begin{array}{l}\text { kelas VIII.B } \\
\text { ekperimen } \\
\begin{array}{l}\text { kelas VIII.D } \\
\text { control } \\
\text { Valid N (listwise) }\end{array}\end{array}$ & 28 & 20 & 70 & 90 & 80.93 & 1.152 & 6.098 & 37.180 \\
\hline
\end{tabular}

Dari tabel diatas terlihat bahwa kategori tinggi, sedang, dan rendah variabel kelas. Kategori tinggi apabila peserta didik memperoleh nilai diatas rata-rata $+\mathrm{SD}$ yaitu $80,93+6,10=87,03$. Kategori sedang apabila peserta didik memperoleh nilai antara rata-rata + SD dengan rata-rata $-S D$ yaitu $80,93-6,10=74,83$ dengan $80,93+6,10=87,03$. Kategori rendah apabila peserta didik memperoleh nilai dibawah rata-rata $-\mathrm{SD}$ yaitu $80,93-6,10=74,83$.

Tabel 2. Kategori Angket Kelas VIII.B Ekperimen Setiap Kategori

\begin{tabular}{|c|c|c|c|}
\hline Kelas VIII.B Eksperimen & Skor & Frekuensi (f) & Presentase (\%) \\
\hline Tinggi & 87,07 & 2 & $7,1 \%$ \\
Sedang & $74,83-87,07$ & 25 & $89,3 \%$ \\
Rendah & 74,83 & 1 & $3,6 \%$ \\
\hline \multicolumn{2}{|r|}{ Jumlah } & 28 & $100 \%$ \\
\hline
\end{tabular}

Dari tabel diatas terlihat bahwa dapat disimpulkan bahwa kategori nilai kelas VIII.B ekperimen sebesar $89,3 \%$, maka nilai pada variabel kelas VIII.B ekperimen memiliki kategori sedang. Kategori tinggi, sedang, dan rendah variabel kelas VIII.D kontrol. Kategori tinggi apabila peserta didik memperoleh nilai diatas rata-rata + SD yaitu $76,67+9,40=86,07$. Kategori sedang apabila peserta didik memperoleh nilai antara rata-rata + SD dengan rata-rata - SD yaitu $76,67-9,40=67,27$ dengan $76,67+9,40=86,07$. Kategori rendah apabila peserta didik memperoleh nilai dibawah rata-rata $-\mathrm{SD}$ yaitu $76,67-9,40=67,27$.

Tabel 3. Kategori Variabel Kelas VIII.D Kontrol Setiap Kategori

\begin{tabular}{|c|c|c|l|}
\hline Kelas VIII.D Kontrol & Skor & Frekuensi (F) & Persentase ( \%) \\
\hline
\end{tabular}




\section{PENGARUH MEDIA STUDENT WORKSHEET TERHADAP HASIL BELAJAR IPS KELAS VIII DI TINGKAT SMP TERPADU OKU TIMUR}

\begin{tabular}{|c|c|c|c|}
\hline Tinggi & 86,07 & 4 & $14,8 \%$ \\
\hline Sedang & $67,27-86,07$ & 20 & $74,1 \%$ \\
\hline Rendah & 67,27 & 3 & $11,1 \%$ \\
\hline \multicolumn{2}{|c|}{ Jumlah } & $\mathbf{2 7}$ & $\mathbf{1 0 0} \%$ \\
\hline
\end{tabular}

Dari tabel 2.3 dapat disimpulkan bahwa kategori nilai hasil kelas VIII.D kontrol sebesar $74,1 \%$, maka nilai pada variabel kelas VIII.D kontrol memiliki kategori sedang.

Pengujian ini menggunaan kolmogorov smirnov digunakan untu melihat distribusi data yang normal atau tidak. Seperti diketahui asumsi normalitas harus dipenuhi jika kita hendak melakukan analisis paramterik.

Tabel 4. One-Sample Kolmogorov-Smirnov Test

\begin{tabular}{|c|c|c|c|}
\hline & & $\begin{array}{l}\text { Post test VIII.B } \\
\text { Ekperimen }\end{array}$ & \begin{tabular}{|l|}
$\begin{array}{l}\text { Post test VIII.D } \\
\text { Kontrol }\end{array}$ \\
\end{tabular} \\
\hline N & & 28 & 27 \\
\hline \multirow[t]{2}{*}{ Normal Parameters ${ }^{a}$} & Mean & 80.93 & 76.67 \\
\hline & Std. Deviation & 6.098 & 9.405 \\
\hline \multirow[t]{3}{*}{ Most Extreme Differences } & Absolute & .118 & 205 \\
\hline & Positive & .096 & .205 \\
\hline & Negative & -.118 & -.120 \\
\hline Kolmogorov-Smirnov Z & & .625 & 1.066 \\
\hline Asymp. Sig. (2-tailed) & & .830 & .206 \\
\hline
\end{tabular}

Berdasarkan data diatas, dapat ditarik simpulan bahwa variabel kelas VIII.B ekperimen yaitu nilai signifikasi yang diperoleh adalah sebesar $0,830 \quad 0,05$, maka kesimpulannya Ho diterima dan Ha ditolak, artinya distribusi data tersebut normal. Variabel kelas VIII.D kontrol yaitu nilai signifikasi yang diperoleh adalah sebesar 0,206 0,05, maka kesimpulannya Ho diterima dan Ha ditolak, artinya distribusi data tersebut normal. 


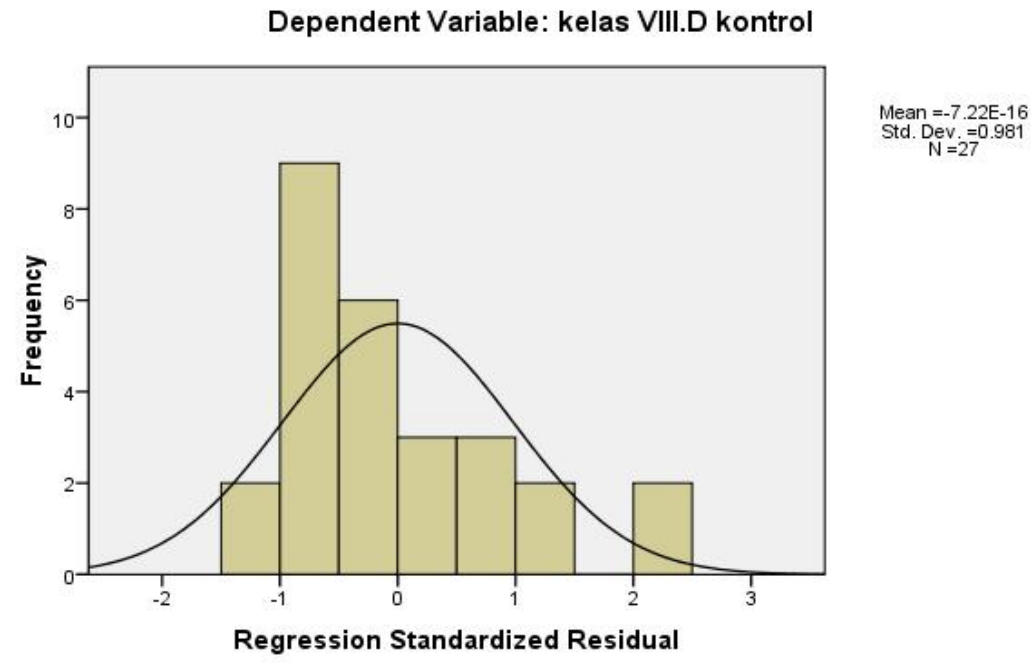

Berdasarkan tampilan di atas dapat dilihat grafik histrogram memberikan pola distribusi yang melenceng ke kanan yang artinya adalah data berdistribusi normal.

Uji homogenitas data digunakan untuk menguji apakah kedua data tersebut homogen. Setelah diketahui bahwa data berdistribusi normal, maka langkah selanjutnya adalah melakukan uji homogenitas varians dengan menggunakanspss versi 20.

Tabel 6. Test of Homogeneity of Variances

Posttest kelas VIII.D kontrol

\begin{tabular}{|c|c|c|c|}
\hline Levene Statistic & $\mathrm{df1}$ & $\mathrm{df} 2$ & Sig. \\
\hline 2.492 & 8 & 16 & .057 \\
\hline
\end{tabular}

Berdasarkan tabel di atas terdapat kelas ekpsperimen dan kontrol diperoleh nilai signifikasi sebesar 0,57 . nilai sig 0,05 maka dapat disimpulkan bahwa data tersebut berasal dari populasi dengan varians yang sama atau homogen.

Tabel 7. Anova

\begin{tabular}{|l|l|l|l|l|l|}
\cline { 2 - 6 } \multicolumn{1}{l|}{ Posttest VIII.D kontrol } & & & & & \\
\hline & Sum of Squares & Df & Mean Square & F & Sig. \\
\hline
\end{tabular}




\section{PENGARUH MEDIA STUDENT WORKSHEET TERHADAP HASIL BELAJAR IPS KELAS VIII DI TINGKAT SMP TERPADU OKU TIMUR}

\begin{tabular}{|c|c|c|c|c|c|}
\hline Between Groups & 1758.333 & 10 & 175.833 & 5.194 & .002 \\
\hline Within Groups & 541.667 & 16 & 33.854 & & \\
\hline Total & 2300.000 & 26 & & & \\
\hline
\end{tabular}

Pengujian homogen di atas menghasilkan dua tabel yaitu Tabel Test Of Homogeneity Of Variances dan tabel ANOVA. Berdasarkan hasil di atas terdapat nilai signifikasi yang dihasilkan oleh tabel Test Of Homogeneity Of Variances sebesar 0,57 . nilai sig 0,05 sehingga dapat disimpulkan bahwa kelas VIII.B eksperimen dan kelas VIII.D kontrol mempunyai varian yang sama atau homogen.

Uji hipotesis dalam penelitian ini yaitu uji t-hitung, yang berfungsi untuk mengetahui pengaruh secara persial antara variabel bebas dengan variabel terikat.

Tabel 8. Coefficients

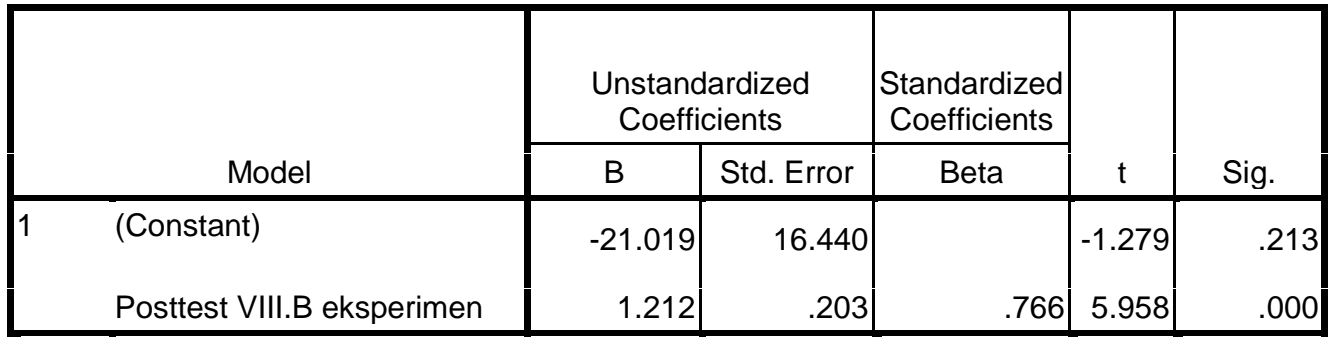

a. Dependent Variable: kelas VIII.D kontol

Dalam hal ini ada dua cara pengambilan keputusan, pertama dengan melihat nilai signifikansi (sig) dengan tingkat signifikan di atas 0,05 yaitu 0,000 . Kedua membandingkan antara nilai $t$ hitung dangan $t$ tabel yaitu nilai $t$ hitung adalah sebesar 5.958 sedangkan $t$ tabel sebesar 2.120 yaitu $t$ hitung $t$ tabel yang artinya bahwa Ho diterima. Hal ini berarti keadaan siswa kelas VIII.B ekperimen diberi perlakuan angket mengenai student worksheet mempunyai kemampuan yang berbeda terhadap kelas VIII.D kontrol dengan diberi perlakuan angket tes mengenai pelajaran IPS.

Berdasarkan hasil perhitungan secara parsial pengaruh penerapan media student worksheet di SMP Terpadu Pondok Pesantren Nurul Huda diperoleh koefisien regresi (b1) sebesar 1.212 dengan t sebesar 5,958 dan Sig sebesar 0,000. Karena nilai sig $\quad 0,05$ maka $\mathrm{H} 0$ diterima. Berdasarkan kriteria yang telah disebutkan di atas maka bisa diambil kesimpulan bahwa berpengaruh positif dan signifikan penerapan media student worksheet di SMP Terpadu Pondok Pesantren Nurul Huda. $\mathrm{Hal}$ ini berarti bahwa penggunaan media student worksheet aktifitas belajar siswa meningkat dari kriteria sedang menjadi aktif. 


\section{PEMBAHASAN}

Berdasarkan data penelitian yang dianalisis maka dilakukan pembahasan tentang hasil penelitian. Penerapan media student worksheet di SMP Terpadu Pondok Pesantren Nurul Huda. Berdasarkan hasil analisa yang dilakukan data diperoleh skor kuesioner yang menunjukan bahwa sebanyak 25 peserta didik $(89,3 \%)$ menjawab kategori sedang, peserta didik $(7,1 \%)$ menjawab kategori tinggi, dan 1 peserta didik $(3,6 \%)$ memberikan jawaban kategori rendah. Dengan demikian bahwa media student worksheet dapat membantu siswa, melatih kemandirian siswa dalam proses belajar serta memudahkan guru dalam memberikan tugas kepada peserta didik. Menurut (Danim, 2010:7) menyatakan bahwa "Media pendidikan merupakan seperangkat alat bantu atau pelengkap yang digunakan oleh guru atau pendidik dalam rangka berkomunikasi dengan siswa atau peserta didik" Namun demikian, media bukan hanya berupa alat atau bahan saja, akan tetapi hal-hal lain yang memungkinkan siswa dapat memperoleh pengetahuan. Penelitian lain yang mendukung penelitian ini adalah penelitian yang dilakukan oleh Ade Ayu Eres Setyarini (2016) yang berjudul "Pengaruh Penerapan Model Cooperative Learning Tipe Think Talk Write dengan Media Lembar Kerja Siswa terhadap Hasil Belajar IPS Siswa Kelas IV SD Negeri 8 Metro Utara Tahun Pelajaran 2015/2016". Seperti dijelaskan oleh Menurut Ismayati (2016) Student worksheet adalah sebagai alat bantu siswa dalam memahami konsep dengan bantuan beberapa pertanyaan yang terarah. Student worksheet dapat memberikan kesempatan pada mahasiswa untuk mengungkapkan pengetahuan dan keterampilannya dalam mengembangkan proses berfikirnya. Dalam pembelajaran ini dapat meningkatkan cara belajar siswa aktif, LKS adalah media pembelajaran yang praktis dan harga terjangkau bagi semua kalangan siswa, siswa dapat berinteraksi dengan sesama teman.

Hasil belajar IPS peserta didik kelas VIII di SMP Terpadu Pondok Pesantren Nurul Huda. Hasil belajar IPS peserta didik kelas VII SMP Negeri 1 Belitang III adalah sedang. Hal tersebut dibuktikan bahwa perolehan skor kuesioner yang menunjukan bahwa sebanyak 20 peserta didik $(74,1 \%)$ menjawab kategori sedang, 4 peserta didik (14,8\%) menjawab kategori tinggi, dan 3 peserta didik $(11,1 \%)$ memberikan jawaban kategori rendah. Data tersebut menunjukkan bahwa hasil belajar siswa adalah sedang. Menurut Sudjana (2009:22) menjelaskan bahwa hasil belajar adalah "kemampuan-kemampuan yang dimiliki siswa setelah ia menerima pengalaman belajarnya". Kemampuan - kemampuan siswa setelah aktivitas belajar yang menjadi hasil perolehan belajar. Dengan demikian hasil belajar adalah perubahan yang terjadi pada individu setelah mengalami pembelajaran.

Pengaruh media student worksheet terhadap hasil belajar IPS kelas VIII di SMP Terpadu Pondok Pesantren Nurul Huda. Hal ini dapat dilihat dari nilai deskriptif analisis data antara kedua variabel yaitu kelas VIII.B eksperimen dan kelas VIII.D kontrol dimana kelas VIII.B eksperimen memiliki nilai tertinggi sebesar $89,3 \%$ sedangkan kelas VIII.D. kontrol sebesar $74,1 \%$ dari nilai tersebut terlihat bahwa hasil 


\section{PENGARUH MEDIA STUDENT WORKSHEET TERHADAP HASIL BELAJAR IPS KELAS VIII DI TINGKAT SMP TERPADU OKU TIMUR}

belajar eksperimen lebih tinggi dibandingkan kelas kontrol. Dari analisis data nilai diperoleh data nilai berdistribusi normal kelas eksperimen 0,830 dan kelas kontrol sebesar 0,206 dan data homogen yaitu sebesar 0,57. nilai sig 0,05 yang artinya homogen serta melalui perhitungan uji -t dapat dibuktikan Ho diterima yang berarti ada efektivitas yang signifikan media student worksheet terhadap hasil belajar IPS kelas VIII di SMP Terpadu Pondok Pesantren Nurul Huda.

\section{SIMPULAN}

Berdasarkan analisis data hasil penelitian, dapat diambil simpulan sebagai jawaban rumusan masalah penelitian. Penerapan media student worksheet di SMP Terpadu Pondok Pesantren Nurul Huda adalah kategori sedang. Berdasarkan hasil analisa data diperoleh skor kuesioner yang menunjukan bahwa sebanyak 25 peserta didik $(89,3 \%)$ menjawab kategori sedang, 2 peserta didik $(7,1 \%)$ menjawab kategori tinggi, dan 1 peserta didik (3,6\%) memberikan jawaban kategori rendah. Dengan demikian bahwa media student worksheet dapat membantu siswa, melatih kemandirian siswa dalam proses belajar serta memudahkan guru dalam memberikan tugas kepada peserta didik.

Hasil belajar IPS peserta didik kelas VIII di SMP Terpadu Pondok Pesantren Nurul Huda adalah kategori sedang. Berdasarkan hasil analisa data diperoleh skor kuesioner yang menunjukan bahwa sebanyak 20 peserta didik $(74,1 \%)$ menjawab kategori sedang, 4 peserta didik (14,8\%) menjawab kategori tinggi, dan 3 peserta didik $(11,1 \%)$ memberikan jawaban kategori rendah. Dengan demikian bahwa hasil belajar adalah perubahan yang terjadi pada individu setelah mengalami pembelajaran.

Terdapat pengaruh yang signifikan media student worksheet terhadap hasil belajar IPS kelas VIII di SMP Terpadu Pondok Pesantren Nurul Huda. Diperoleh berdasarkan analisis deskriptif kelas eksperimen memperoleh nilai hasil belajar sebesar $89,3 \%$ sedangkan kelas kontrol sebesar $74,1 \%$. Dari analisis data nilai diperoleh data nilai berdistribusi normal kelas eksperimen 0,830 dan kelas kontrol sebesar 0,206 dan data homogen yaitu sebesar 0,57. nilai sig 0,05 yang artinya homogen serta melalui perhitungan uji -t dapat dibuktikan Ho diterima yang berarti ada pengaruh yang signifikan media student worksheet terhadap hasil belajar IPS kelas VIII di SMP Terpadu Pondok Pesantren Nurul Huda. Dengan demikian media student worksheet sangat membantu siswa di SMP Terpadu Pondok Pesantren Nurul Huda karena sekolahan ini berbasis pondok pesantren dimana akses internet masih terbatas sehingga masih mengandalkan guru sebagai sumber utama mendapatkan materi pokok. 


\section{SARAN}

- Bagi Sekolah

Hendaknya dapat meningkatkan kualitas pendidikan dari pembelajaran peserta didik dengan memotivasi supaya lebih aktif dalam belajar dan meningkatkan sarana dan prasarana pembelajaran yang menunjang.

- Bagi Guru

Harus lebih memahami kondisi dan karakter peserta didik yang mempunyai tingkat kecerdasan yang berbeda-beda, sehingga guru tepat dalam menentukan metode mengajar agar siswa dapat memecahkan masalah sendiri pada materi pembelajaran IPS dengan lebih baik lagi.

- Bagi Siswa

Hendaknya lebih meningkatkan intesitas belajarnya dengan memiliki keinginan untuk mandiri dalam belajar yang baik agar dapat termotivasi dan dapat memecahkan masalah sendiri pada materi pembelajaran IPS dengan lebih baik lagi. Selain itu, peserta didik harus berani bertanya kepada guru apabila menemui kesulitan dalam memahami pelajaran dan mencari buku referensi lain yang dapat dijadikan acuan untuk menambah penngetahuan.

- Bagi Penelitian Selanjutnya

Peneliti selanjutnya hendaknya dapat melakukan penelitian terhadap penerapan media student worksheet pada pembelajaran IPS secara lebih terfokus seperti pada bentuk penelitian sebelumnya seperti penelitian tindakan kelas agar memperkuat hasil penelitian yang telah dilakukan.

\section{REFERENSI}

Afifurrahman. 2017. "Pemanfaatan Bahan Ajar Lembar Kerja Siswa (LKS) Dalam Pembelajaran Mata Pelajaran Sejarah Kebudayaan Islam Pada Siswa Kelas VIII B Di Madrasah Tsanawiyah Negeri (MTs N) Manyaran Kabupaten Wonogiri Tahun Ajaran 2015/2016".

Ahmad, S. 2016. Teori Belajar dan Pembelajaran. Jakarta: Prenada Media Group.

Aryaningrum, Kiki. 2015 "Pengaruh Strategi Pembelajaran Everyone Is a Teacher Here Terhadap Hasil Belajar Siswa Pada Mata Pelajaran IPS Terpadi (Geografi) Di kelas VIII SMP Negeri 1 Belitang III Oku Timur".

Dalyono. 2009. Psikologi Pendidikan. Jakarta: PT. Rineka Cipta.

Danim. 2010. Pengantar Kependidikan. Bandung: Alfabeta.

Departemen pendidikan nasional. 2010. Undang-undang RI No.20 Tahun 2003. Tentang Sistem Pendidikan Nasional. Jakarta:Depdiknas.

Hamalik. 2008. Kurikulum dan Pembelajaran. Bumi Aksara, Jakarta. 2013. Proses Belajar Mengajar. Jakarta: PT. Bumi Aksara. 


\section{PENGARUH MEDIA STUDENT WORKSHEET TERHADAP HASIL BELAJAR IPS KELAS VIII DI TINGKAT SMP TERPADU OKU TIMUR}

Hendri, met. 2011. "Penerapan Lembar Kerja Siswa (LKS) Oleh Guru Bidang Studi Pendidikan Agama Islam Dalam Pembelajaran Agama Islam Di SMP Negeri 21 Pekan Baru".

Mukhtar. 2015. Hubungan Motivasi Belajar Dengan Hasil Belajar Pada Mata Pelajaran Seni Budaya Bidang Seni Musik Siswa Kelas X SMA Piri 1 Yogyakarta. Skripsi Sarjana pada Seni Musik FBS UNY Yogyakarta: tidak diterbitkan.

Prastowo. 2011. Panduan Kreatif Membuat Bahan Ajar Inovatif: Menciptakan Metode Pembelajaran yang Menarik dan Menyenangkan. Yogyakarta: Diva Press.

Purwanto. 2013. Evaluasi Hasil Belajar. Yogyakarta: Pustaka Pelajar.

Purnamawati. 2001. Media Pembelajaran. Jakarta: CV. Rajawali.

Rifa'i, Cathariana. 2009. Psikologi Pendidikan. Semarang: Universitas Negeri Semarang Press.

Rusman. 2012. Belajar dan Pembelajaran Berbasis Komputer Mengembangkan Profesionalisme Guru Abad 21. Bandung: Alfabeta.

Rustaman. 2001. Pengertian Pembelajaran Menurut Para Ahli. Hal: 461

Sanjaya. 2012. Media Komunikasi Pembelajaran. Jakarta: Kencana Prenada Media Group.

Sardiman. 2011. Interaksi dan Motivasi Belajar Mengajar. Jakarta: Rajawali Press.

Slameto. 2010. Belajar dan Faktor-Faktor Yang Mempengaruhinya. Jakarta: PT. Rineka Cipta.

Sudjana. 2009. Penilaian Hasil Proses Belajar Mengajar. Bandung: PT. Remaja Rosdakarya.

Sugihartono. dkk. 2013. Psikologi Pendidikan. Yogyakarta: UNY Press.

Suwardi, dkk. 2014 "Pengaruh Penggunaan Alat Peraga terhadap Hasil Pembelajaran Matematika pada Anak Usia Dini”.

Wakhinudin. 2009. Belajar dan Faktor-Faktor Yang Mempengaruhinya. (online), (https://subenoarifwibowo.wordpress.com/2011/05/15/pengertian-hasilbelajar/amp), (diakses tanggal 4 Agustus 2019). 